We wish to thank Mr. J. E. Piercy, Mr. M. J. Lange, and Dr. A. Stuart Mason for their kind permission to study patients under their care.

\section{REFERENCES}

Bartels, E. C., and Kingsley, J. W., jun. (1949). Lahey Clin. Bull., 6, 101.

Bird, R., and Jackson, D. J. (1962). Clin. Chem., 8, 389.

Burnet, M. (1962). Proc. roy. Soc. Med., 55, 619.

Carson, J., and Keynes, G. L. (1942). Ibid., 36, 140.

Churchill-Davidson, H. C., and Richardson, A. T. (1952). Ibid., 45, 179.

Cohen, S. J., and King, F. H. (1932). Arch. Neurol. Psychiat. (Chic.), $28,1338$.

Daly, J. J., and Jackson, E. (1964). Brit. med. 7., 1, 748.

Drachman, D. B. (1962). New Engl. F. Med., 266, 330.

Dudgeon, L. S., and Urquhart, A. L. (1926). Brain, 49, 182.

Engel, A. G. (1961). Arch. Neurol. (Chic.), 4, 663.

Farran, H. E. A. (1958). Brit. med. F., 2, 1060.

Feinberg, W. D., Underdahl, L. O., and Eaton, L. M. (1957). Proc. Mayo Clin., 32, 299.

Fraser, R. (1956). Lancet, 2, 581.

Garvey, J. L. (1930). Ann. intern. Med., 3, 917.
Giordano, A. S., and Haymond, J. L. (1944). Amer. F. clin. Path., 14, 253.

Greene, R. (1949). Proc. roy. Soc. Med., 42, 263.

(1950). F. Endocr., 7, 1 .

and Artunkal, S. (1958). Türk. Tip. Cem. Mec., 24, 199.

- Rideout, D. F., and Shaw, M. L. (1961). Lancet, 2, 281.

Hamolsky, M. W. "Golodetz, A., and Freedberg, A. S. (1959). F. clin. Endocr., 19, 103.

Kowallis, G. F., Haines, S. F., and Pemberton, J. de J. (1941). Proc. Mayo Clin., 16, 545.

Levy, G., Meadows, W. R., and Gunnar, R. M. (1951). Ann. intern Med., 35, 134.

McEachern, D., and Parnell, J. L. (1948). f. clin. Endocr., 8, 842.

Maclean, B., and Wilson, J. A. C. (1954). Lancet, 1, 950.

Millikan, C. H., and Haines, S. F. (1953). Arch. intern. Med., 92, 5.

Rennie, G. E. (1908). Rev. Neurol. Psychiat., 6, 229.

Ringertz, N. (1951). Acta path. microbiol. scand., $29,9$.

Roitt, I. M., Doniach, D., Campbell, P. N., and Hudson, R. V. (1956) Lancet, 2, 820 .

Sheldon, J. H., and Walker, R. M. (1946). Ibid., 1, 342.

Silver, S., and Osserman, K. E. (1957). F. Mt Sinai Hosp., 24, 1214.

Storm-Mathisen, A. (1961). Myasthenia Gravis. Aschehoug, Oslo.

Thorner, M. W. (1939). Arch. intern. Med., 64, 330.

Weigert and Laquer (1901). Neurol. Cent., 20, 594.

\title{
Detection of Bacteriuria by a Modification of the Nitrite Test
}

\author{
J. DOUGLAS SLEIGH,* M.B., CH.B., M.C.PATH.
}

Brit. med. F., 1965, 1, 765-767

Urinary infections are characterized by periods when bacteria, almost always coliform organisms, multiply in the urine within the urinary tract. When this happens the urine usually contains 100,000 or more bacteria per ml. (significant bacteriuria), whereas lower numbers of organisms are most often contaminants which have entered the urine from the urethra or external genitalia while the specimen was being voided (Kass, 1955). Significant bacteriuria, which may be asymptomatic, seems to be related to active pyelonephritis (MacDonald et al., 1957) and probably to the development and progression of chronic pyelonephritis (Quinn and Kass, 1960). The recognition of significant bacteriuria by enumeration of the bacteria in each millilitre of urine, however, is laborious and expensive, and large-scale surveys to detect patients with asymptomatic bacteriuria would be greatly facilitated by the use of a simple and reliable screening test.

Nitrites, which are easy to detect chemically, are not found in normal urine, and it was Cruickshank and Moyes (1914) who noted that the presence of nitrites in urine was associated with coliform bacteriuria. This nitrite is formed from the nitrate in urine by bacterial action. However, when the nitrite test is applied to specimens of freshly voided urine only about half of those with significant bacteriuria give a positive result. This study was undertaken to see if it was possible to increase the usefulness of the nitrite reaction as a test for bacteriuria.

\section{Materials and Methods}

During this study 1,530 urine specimens were examined. All were mid-stream specimens passed either without preparation or after simple washing of the genital region by the patient. The majority of the urines came from women attending either an antenatal or an infertility clinic, and these specimens reached the laboratory within two hours of being voided. The rest of the specimens were from patients who had consulted their

* Lecturer in Bacteriology, University of Edinburgh. general practitioners, and most, but not all, of them were submitted in special containers which maintain a low temperature during transit (Elliott and Sleigh, 1963). When the specimens of urine reached the laboratory they were either examined at once or refrigerated until the following morning. Every specimen was cultured quantitatively by dropping known volumes of urine, diluted and undiluted, on to the surface of blood-agar plates.

The presence of nitrite in urine was detected by the Ilosvay modification of the Griess test. The reagents used were: solution A, $1.25 \mathrm{~g}$. of sulphanilic acid in $500 \mathrm{ml}$. of $30 \%$ acetic acid; solution $\mathrm{B}, 2.5 \mathrm{~g}$. of $\alpha$-naphthylamine in $500 \mathrm{ml}$. of $30 \%$ acetic acid. Each day equal volumes of solutions A and $\mathrm{B}$ were mixed together and the test was performed by adding $1 \mathrm{ml}$. of the resulting solution to $1 \mathrm{ml}$. of urine. If a red or pink colour developed the test was regarded as positive.

The first part of the investigation concerned 530 urines. All these urines were first examined for nitrites; this initial test was positive in 30 and negative in 500 . Twelve $1-\mathrm{ml}$. aliquots were then taken from each specimen and to six of them two $0.02-\mathrm{ml}$. drops of a $5 \%$ solution of potassium nitrate in distilled water were added. The samples were then placed in an incubator at $37^{\circ} \mathrm{C}$. for six hours. At hourly intervals two samples, one with and one without added nitrate, were tested for the presence of nitrites.

The second part of the investigation dealt with 1,000 urines which were not examined for nitrites initially. The ability of a modified nitrite test to detect significant bacteriuria in these specimens was compared with that of the triphenyl tetrazolium chloride (T.T.C.) test of Simmons and Williams (1962). In the modified test which was developed from the results of the first part of the study $1 \mathrm{ml}$. of urine, with added nitrate, was incubated undisturbed in a water-bath at $37^{\circ} \mathrm{C}$. for four hours before being tested for nitrites. The T.T.C. test was carried out by the method of Simmons and Williams (1962) but using $1 \mathrm{ml}$. of urine and $0.25 \mathrm{ml}$. of the working solution of T.T.C. This test was read after four hours' incubation in 
a water-bath at $37^{\circ} \mathrm{C}$, and considered to be positive not only if there was a distinctly red precipitate but whenever any red or pink coloration of the precipitate was observed.

\section{Results}

The way in which the bacterial counts, carried out on all 1,530 specimens, were interpreted is shown in Table I. Of

TABLE I.-Interpretation of the Result of Quantitative Urine Culture in 1,530 Specimens

\begin{tabular}{|c|c|c|}
\hline Result of Urine Culture & Conclusion & $\begin{array}{c}\text { No. of } \\
\text { Specimens }\end{array}$ \\
\hline $\begin{array}{l}\text { Urines which gave no growth or yielded a mixed } \\
\text { growth of contaminants }\end{array}$ & $\begin{array}{c}\text { Insignificant } \\
\text { bacteriuria }\end{array}$ & 1,332 \\
\hline $\begin{array}{l}\text { Urines containing coliform bacilli at concentrations } \\
\text { between } 10^{4} \text { and } 10^{5} / \mathrm{ml} \text {. either in pure culture } \\
\text { or along with other organisms. } \\
\text { Urines containing Staphylococcus albus in pure }\end{array}$ & $\left\{\begin{array}{l}\text { Bacteriuria } \\
\text { of doubtful } \\
\text { significance }\end{array}\right.$ & 38 \\
\hline $\begin{array}{l}\text { Urines containing urinary-tract pathogens at con- } \\
\text { centrations between } 10^{5} \text { and } 10^{8} / \mathrm{ml} \text {. }\end{array}$ & $\begin{array}{l}\text { Significant } \\
\text { bacteriuria }\end{array}$ & 160 \\
\hline
\end{tabular}

the 1,332 urines with insignificant bacteriuria, $612(46 \%)$ contained fewer than $10^{3}$ organisms per $\mathrm{ml}$. and $356(27 \%)$ between $10^{3}$ and $10^{4}$ organisms per $\mathrm{ml}$. ; the remaining 364 specimens $(27 \%)$ were heavily contaminated and on culture yielded mixtures of organisms non-pathogenic in the urinary tract at concentrations of $10^{4}$ or $10^{5} / \mathrm{ml}$. In 38 of the 1,530 specimens the significance of the bacteriuria was difficult to assess. Some or all of the organisms in those specimens may have been contaminants which entered the urine during micturition. The identity of the bacteria isolated from the 160 specimens with significant bacteriuria was determined (Table II).

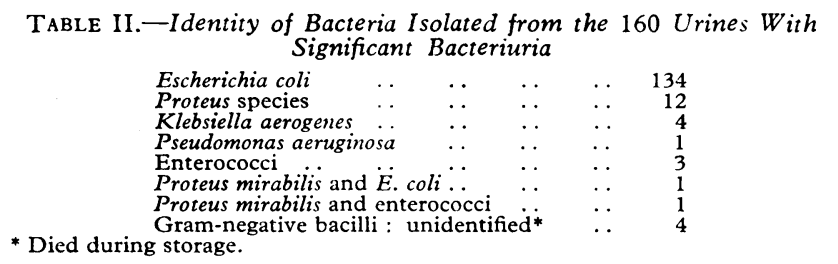

The results of the first part of the investigation are detailed in Table III. Of the 59 urines with significant bacteriuria but giving initially negative nitrite tests, 57 gave positive results after six hours' incubation with added nitrate ; in the remaining two urines the infecting organism was an enterococcus. The number of positive nitrite tests recorded after each hour of incubation is substantially increased by the addition of nitrate to initially nitrite-negative specimens with significant bacteriuria. In the same series tested without added nitrate the initial increase in positive tests apparently ceases after the fourth hour (see Table III) ; this is because nitrite was detected in nine samples at some stage during the six-hour incubation period, but these specimens subsequently gave negative tests while other samples were developing and maintaining positive reactions. This succession of changes in the nitrite test during incubation (negative-positive-negative) was never observed if extra substrate had been added to the specimen. The nitrite test remained positive throughout the incubation period in all 30 of the urines with significant bacteriuria which initially gave a positive test, if nitrate had been added. In the parallel series without added nitrate, however, 5 of the 30 urines developed negative tests by the end of the incubation period. These findings indicate that occasionally the naturally available nitrate was insufficient to compensate for further decomposition of nitrite during the test period.

Even after six hours' incubation only 12 of the 420 urines with insignificant bacteriuria produced a positive nitrite reaction (Table III); 10 of these 12 urines were heavily contaminated.

The efficiency of the modified nitrite test in detecting significant bacteriuria was then compared with that of the T.T.C. test (Table IV). Of the 71 specimens with significant

TABLE IV.-Comparison of the Ability of Two Different Screenin, Methods to Detect Bacteriuria in 1,000 Specimens

\begin{tabular}{|c|c|c|c|c|c|}
\hline \multirow{3}{*}{$\begin{array}{l}\text { Result of Quantitative } \\
\text { Urine Culture }\end{array}$} & \multirow{3}{*}{$\begin{array}{l}\text { No. of } \\
\text { Specimens }\end{array}$} & \multicolumn{4}{|c|}{ Screening Method } \\
\hline & & \multicolumn{2}{|c|}{$\begin{array}{l}\text { Modified } \\
\text { Nitrite Test }\end{array}$} & \multicolumn{2}{|c|}{ T.T.C. Test } \\
\hline & & Pos. & Neg. & Pos. & Neg \\
\hline $\begin{array}{l}\text { Insignificant bacteriuria } \\
\text { Bacteriuria of doubtful signifi- }\end{array}$ & 912 & 15 & 897 & 17 & 895 \\
\hline $\begin{array}{ll}\text { cance } & \ldots\end{array}$ & $\begin{array}{l}17 \\
71\end{array}$ & $\begin{array}{l}13 \\
69\end{array}$ & $\begin{array}{l}4 \\
2\end{array}$ & $\begin{array}{r}6 \\
54\end{array}$ & $\begin{array}{l}11 \\
17\end{array}$ \\
\hline
\end{tabular}

bacteriuria $69(97 \%)$ were detected by the modified nitrite test whereas $54(76 \%)$ were recognized by the T.T.C. test. The infecting organisms isolated from the two specimens of urine where the modified nitrite test failed were an enterococcus and $E$. coli at a concentration of $10^{5}$ organisms per $\mathrm{ml}$. The number of false-positive reactions in the 912 urines with insignificant bacteriuria was small, being only $15(1.6 \%)$ with the modified nitrite test and $17(1.9 \%)$ with the T.T.C. test. Almost all these false-positive tests were recorded in heavily contaminated urines.

\section{Discussion}

The need for a simple yet accurate test to detect bacteriuria is now widely recognized (Lancet, 1964), especially for carrying out epidemiological studies to determine the incidence and distribution of asymptomatic urinary infection. There is no general agreement, however, about the best test to use ; semiquantitative urine culture requires bacteriological facilities and technical skill, and even if microscopy of a Gram-stained film of the uncentrifuged urine (Kass, 1957) is an accurate screening method, considerable experience is necessary to interpret the result.

The attraction of an easily read chemical test is obvious, but none of those described so far has given consistently reliable results. In published reports the success of the nitrite test, performed on a freshly voided urine specimen, in detecting bacteriuria has varied from 40 to $80 \%$ (Bechgaard and Jansen, 1943 ; Smith et al., 1961 ; Turner, 1961 ; Sleigh et al., 1964). It has been suggested, however, that the chance of recognizing bacteriuria by the nitrite test improves when several specimens are examined from the same patient (Sleigh et al., 1964).

TABLE III.-Number of Positive Nitrite Tests Recorded Each Hour when 530 Urine Specimens which Initially Gave Either a Nesative or Positive Reaction were Incubated at $37^{\circ} \mathrm{C}$. With or Without Added Nitrate

\begin{tabular}{|c|c|c|c|c|c|c|c|c|c|c|c|c|c|c|c|}
\hline \multirow{4}{*}{\multicolumn{2}{|c|}{ Result of Quantitative Urine Culture }} & \multirow{4}{*}{$\begin{array}{c}\text { Initial } \\
\text { Nitrite } \\
\text { Test }\end{array}$} & \multirow{4}{*}{$\begin{array}{l}\text { No. of } \\
\text { Specimens }\end{array}$} & \multicolumn{12}{|c|}{ No. of Positive Nitrite Tests Recorded } \\
\hline & & & & \multicolumn{6}{|c|}{ Without Added Nitrate } & \multicolumn{6}{|c|}{ With Added Nitrate } \\
\hline & & & & \multicolumn{6}{|c|}{ Hours of Incubation } & \multicolumn{6}{|c|}{ Hours of Incubation } \\
\hline & & & & 1 & 2 & 3 & 4 & 5 & 6 & 1 & 2 & 3 & 4 & 5 & 6 \\
\hline $\begin{array}{l}\text { Insignificant bacteriuria } \\
\text { Bacteriuria of doubtful significance } \\
\text { Significant bacteriuria } \\
\text { Significant bacteriuria }\end{array}$ & $\begin{array}{l}\ldots \\
\cdots \\
\cdots\end{array}$ & $\begin{array}{l}\text { Negative } \\
\text { Negative } \\
\text { Negative } \\
\text { Positive }\end{array}$ & $\begin{array}{r}420 \\
21 \\
59 \\
30\end{array}$ & $\overline{6}$ & $\overline{10}$ & $\overline{-}$ & $\begin{array}{r}2 \\
36 \\
27\end{array}$ & $\begin{array}{r}4 \\
5 \\
35 \\
26\end{array}$ & $\begin{array}{l}11 \\
10 \\
35 \\
25\end{array}$ & $\begin{array}{l}\overline{1} \\
\overline{13} \\
30\end{array}$ & $\frac{-}{20}$ & $\begin{array}{l}-- \\
\overline{40} \\
30\end{array}$ & $\begin{array}{r}1 \\
2 \\
52 \\
30\end{array}$ & $\begin{array}{r}4 \\
7 \\
54 \\
30\end{array}$ & $\begin{array}{l}12 \\
13 \\
57 \\
30\end{array}$ \\
\hline
\end{tabular}


Schaus (1956) discussed the possible reasons for the failure of the nitrite test; he stated that false-negative reactions could be eliminated by adding a few drops of a $10 \%$ solution of sodium nitrate to the urine and incubating for two hours at $37^{\circ}$ C. before carrying out the test. However, he produced no evidence to support this claim. Kahler and Guze (1957) evaluated the nitrite test on theoretical grounds. They grew different numbers of two strains of $E$. coli and three other Gram-negative bacilli in broth and urine to which nitrate had been added, and found the time necessary for the bacteria to produce nitrite. When the initial concentration of organisms was of the order of $10^{4} / \mathrm{ml}$. the time required varied from four and a half to seven hours, if $10^{5} / \mathrm{ml}$. four to five hours, but they concluded that, even if modified as suggested by Schaus, the test could only be of limited value for detecting significant bacteriuria. Smith et al. (1961) then described a modification of the nitrite test in which the urine, with added nitrate, was left at room temperature for one hour before being tested for nitrites, but they found that this did not greatly improve the ability of the nitrite test to recognize bacteriuria. This modification was subsequently employed by Williams and Simmons (1963) and by Kincaid-Smith et al. (1964) with disappointing results.

The modification proposed here has proved extremely successful in the detection of bacteriuria caused by Gramnegative bacilli. At $37^{\circ} \mathrm{C}$. in an incubator it required about six hours for the production of the greatest number of truepositive reactions, but it was possible to shorten this time to four hours, without diminishing the sensitivity of the test, when incubation was allowed to proceed undisturbed in a water-bath. Carried out in this way the incidence of falsepositive results is less than $2 \%$. Examination of Table III shows that the addition of extra nitrate is necessary. It seems that nitrate may be either absent from the voided urine or present in such small amounts that during incubation it is all reduced to nitrite, which in turn is further decomposed by bacterial action resulting in the production of a negative test.

In this investigation the T.T.C. test was able to detect $75 \%$ of the urines with significant bacteriuria. At present the T.T.C. test is the most popular chemical test for bacteriuria, and Williams and Simmons (1963) reported that it could recognize about $90 \%$ of infected urines. This finding has been confirmed by other workers (Chard and Cole, 1963; Deutch and Jespersen, 1964 ; Kincaid-Smith et al., 1964), but there has not been universal agreement about the reliability of the test, because Steers and Jackson (1963), Guze and Kalmanson (1963), and Bulger and Kirby (1963) were able to detect only between 60 and $70 \%$ of the urines that contained more than 100,000 organisms per $\mathrm{ml}$. The possible reasons for this discrepancy have been discussed recently in the Lancet (1964).

The T.T.C. test is more difficult to perform than the nitrite test, since the T.T.C. solution requires careful handling during preparation and subsequent use, and experience is necessary when reading the result of the test. The advantages of the modified nitrite test described here appear to be many: the test is simple to perform, easy to read, and seems very accurate in detecting significant bacteriuria. However, in this study the urine specimens came from patients who usually did not have any past history of urinary infection, and the infecting organism was almost always $E$. coli. The ability to reduce nitrates to nitrites is possessed by all the Gram-negative bacilli belonging to the genera Escherichia, Klebsiclla, Citrobacter,
Proteus, Salmonella, and Shigella, by Pseudomonas aeruginosa, by Staphylococcus aureus and Staphylococcus albus, and by the Providencia group of paracolons, but this property is never found in streptococci. Therefore this test might be less successful if it was applied to urines from patients with chronic infections where the pathogen is more likely to be an organism which either does not reduce nitrate at all-for example, an enterococcus-or does so at a much slower rate-for example, Pseudomonas aeruginosa.

Nevertheless, $E$. coli is the organism most of ten responsible for asymptomatic bacteriuria, and it is hoped that this modification of the nitrite test may prove of value in large-scale surveys designed to recognize patients with unsuspected urinary infection. On a smaller scale, the test may be of use for the routine examination of urine specimens from all patients attending antenatal, infertility, diabetic, and genito-urinary clinics. Pending the result of the screening test the urine specimens should be stored in the refrigerator; if the test is positive the urine is then examined by a standard bacteriological method to ascertain the nature, and preferably also the number, of the bacteria present.

\section{Summary}

The development of a modified nitrite test for the recognition of significant bacteriuria is described. The test involves incubation of the urine, to which nitrate has been added, in a waterbath at $37^{\circ} \mathrm{C}$. for four hours before testing for nitrites. Out of 71 urine specimens with significant bacteriuria 69 (97\%) were detected by this test whereas only $54(76 \%)$ gave a positive triphenyl tetrazolium chloride test; the incidence of falsepositive tests was less than $2 \%$. The possible value of this test in large-scale surveys to detect unsuspected urinary infection is discussed.

I am grateful to Dr. L. Ganguli for her assistance with the laboratory work, and I wish to thank Dr. P. Mestitz for his encouragement. Part of the expenses of this study were defrayed by grants from Messrs. Eli Lilly and Co. Ltd. and from the Secretary of State for Scotland.

\section{REFERENCES}

Bechgaard, P., and Jansen, K. F. (1943). Nord. Med., 20, 2134. Bulger, R. J., and Kirby, W. M. M. (1963). Arch. intern. Med., 112,

Chard, T., and Cole, P. G. (1963). Lancet, 2, 326.

Chard, T., and Cole, P. G. (1963). Lancet, 2, 326.
Cruickshank, J., and Moyes, J. M. (1914). Brit. med. f., 2, 712.

Deutch, M., and Jespersen, H. G. (1964). Acta med. scand., 175, 191. Elliott, W. A., and Sleigh, J. D. (1963). Brit. med. F., 1, 1142.

Guze, L. B., and Kalmanson, G. M. (1963). Amer. F. med. Sci., 246, 691 .

Kahler, R. L., and Guze, L. B. (1957). F. Lab. clin. Med., 49, 934.

Kass, E. H. (1955). Amer. F. Med., 18, 764.

Kincaid-Smith, P., Bullen, M., Mills, J., Fussell, U., Huston, N., and Goon, F. (1964). Lancet, $2,61$.

Lancet, 1964, 2, 77 .

MacDonald, R. A., Levitin, H., Mallory, G. K., and Kass, E. H. (1957). New Engl. 7. Med., 256, 915.

Quinn, E. L.; and Kass, E. H. (1960). Biology of Pyelonephritis, p. 399. Churchill, London.

Schaus, R. (1956). F. Amer. med. Ass., 161, 528.

Simmons, N. A., and Williams, J. D. (1962). Lancet, 1, 1377.

Sleigh, J. D., Robertson, J. G., and Isdale, M. H. (1964). F. Obstet. Gynaec. Brit. Cwlth, 71, 74

Smith, L. G., Thayer, W. R., Malta, E. M., and Utz, J. P. (1961). Ann. intern. Med., 54, 66.

Stcers, E., and Tackson, F. W. (1963). Lancet, 1, 1267.

Turner, G. C. (1961). Ibid., 2, 1062 .

Williams, J. D., and Simmons, N. A. (1963). Ibid., 1, 1373. 